\title{
Transnational corporations, socio-economic change and recurrent crisis
}

\author{
Stephen Ackroyd Lancaster University Management School, Lancaster, UK and \\ Jonathan Murphy \\ Cardiff Business School, Cardiff University, Cardiff, UK
}

\begin{abstract}
This Special Issue of critical perspectives on international businesses addresses a question of fundamental concern to both scholars of international business and citizens around the world: what has changed in the composition and functioning of national economies and the international economic system in order to plunge the global economy into a lengthy and, to date, irresolvable crisis? Early efforts to paper-over the initial financial crisis (usually judged to have begun in late 2007), by bailing out financial institutions and embarking in some tentative, Keynesian-inspired tax cuts and deficit spending to underpin demand, may have averted the risk of total collapse, but growing concern about the risk of ballooning deficits in government borrowing quickly engendered a return to the deflationary policies that had been the main response of government and business elites to the Great Depression of the 1930s. This policy reversal reflects the stranglehold of neoliberal ideology on economic and political thinking almost everywhere: the crisis, no matter how it might have been caused, apparently must be resolved through the sacrifices of ordinary citizens. In Europe, right wing governments which controlled all the major states (until Francois Hollande's victory in France in May 2012) responded to the 'demands of the markets' by imposing austerity measures both externally (and particularly on the countries on the fringes of Europe with weaker economies) and internally, where individual taxpayers and curbs on government spending are the primary source of debt repayments.
\end{abstract}

Across Europe and North America, the standards of living of hundreds of millions of citizens were and are subjected to a three-pronged assault: through tax increases, particularly of consumption taxes that disproportionately affect those with low and moderate incomes; through declining and more costly state services ranging from child-care to health services to higher education, and through reductions in state pensions and benefits for the unemployed and disabled. This assault on ordinary people has been combined with and facilitated by the scape-goating of those at the margins of the economy: economic migrants, Muslims, and 'welfare cheats'. Meanwhile, apart from a few token scalps among the most egregiously irresponsible of financial sector managers, such as British bank RBS's Fred Goodwin, the writ of financial elites remains unchallenged. Here as elsewhere the actions taken by governments were too little too late, and reveal very clearly a lack of understanding by political leaders of the processes that brought about the near collapse of the international economy. Certainly, opposition parties including the erstwhile political left have also proven incapable of advancing substantially different economic policies either in opposition or in power. In addition the capacity for opposition by organised labour (in those countries that had significant union movements) has also rapidly declined. In Britain the potential for independent action by trade unions has been weakened by anti-union legislation and the effectiveness of their organisations has been dramatically, if not fatally, undercut through the operation of neoliberal capitalism in which disarticulated value processes may be relocated to low-wage, lowregulation, authoritarian production environments, of which China is the predominant example.

Of course, there are numerous analyses of the causes of the global economic crisis that attempt an overview and purport to bring the causes to light, both journalistic and more serious (Brummer, 2009; Peston, 2008; Stiglitz, 2009). Indeed, there are even some instances in which writers such as Duncan (2003) and Roubini (2008) predicted the crisis prior to its onset, and correctly identified it as beginning 
with the exotic, poorly understood, and inadequately regulated new financial products such as the infamous collateralized debt obligations (CDOs). As was predicted and as has been exhaustively analysed afterward, these were built upon the sand of insecure income flows from over-extended subprime borrowers drowning in a sea of debt even as their potential for repayment was being further undercut by the wholesale exportation of jobs to developing countries. As many now agree, the bursting of the US housing bubble had a certain inevitability, but we can be far less sure that the causes and the extent of its effects have been fully identified. The type of analysis so far discussed, however accurate it might be in pinpointing the specific moment of economic meltdown in 2007/2008, fails to explain the conditions of possibility for this particular version of financialized capitalism. Why do we now have such a huge over-development of the finance capital sector in Britain and the US, the size of which far exceeds any reasonable estimate of the requirements of the commercial and productive sectors of the economy in the developed world? What has produced the recurrent tendency for finance to oversupply any investment enthusiasm so as to produce speculative bubbles which inevitably collapse and produce recurrent debt crises? Much existing work, in the editors' view, inadequately articulates the thoroughgoing changes to the nature of the international capitalist system that have emerged in the wake of the victory of the neoliberal thought style (Plehwe, 2009; Harvey, 2005) in the 1970s and 1980s. Some solid progress has been and is being made of course, but there is some way to go yet (Duncan, 2007; Brenner, 2006; Harvey, 2010).

This special issue is devoted to understanding and exploring the different features of the broader system of neoliberalized international capitalism that has plunged the world into its current downward economic spiral. Commentators often focus on pressures towards financialization, by which is meant the increasing, indeed ubiquitous, tendency to focus solely on the current returns on investment when evaluating business success. We do not disagree that there are numerous pressures towards financialization, but think it is a symptom as much as a cause of current troubles. One important factor here which is seldom discussed is the existence of a large surplus of under-utilised finance capital. That much of this is liquid and highly mobile is a key feature of the present situation. Jan Fichtner alludes to this in the first paper of this special issue by referring to the way the City of London offered new financial services which facilitated the handling of surplus capital from around the world. Britain (actually the City of London), soon to be followed by the USA (or more particularly, Delaware) offered a range of new investment services to émigré capital, including access to investments denominated in dollars and access to a new range of tax havens substantially beyond the reach of tax authorities (Brittain-Catlin, 2005; Shaxson, 2011). Rapidly mobilised surplus capital which is available to feed any investment enthusiasm, would not have developed to nearly the same extent, had it not been for the huge influxes of capital from various sources in the world attracted by these outlets. Russia and the near-East (with lesser if not less suspect contributions from South American drug cartels and African dictatorships) were amongst the sources of funds that flowed to these centres, and which subsequently found their way into the increasingly large and highly liquid pools of hot money available for investment (Strange, 1998). In the medium term, of course, the pursuit of more reliable income for such capital stimulated the development of new institutions and practices within the centres of finance capitalism in Britain and the USA, including the emergence of the so-called shadow banking system.

In short, in addition to work within the discipline of economics, there is a need for a much more adequate consideration of the institutional developments within finance capitalism that have allowed new economic processes to enact markets in the destabilising way that they now do. It is here that this special issue begins to make its contribution, by adding to our understanding of the working of key new institutions from a social science perspective. 


\section{New financial institutions within capitalism}

A special issue of this journal can be expected to offer some commentary on the impact of financial developments on international businesses, and we shall do so in the next section. However, it is a necessary preliminary to discuss some of the institutional developments that have caused the pressures from finance on business to take particular forms. There is an emerging set of new financial institutions that not only radically alter the structure of the companies they acquire, but also indirectly shape the behaviour of the executives forming policy for many other companies and lead them to transform the structure of their companies as well.

Until recently it might have been thought that what we see today is simply the extension of wellestablished trends within Western economies towards short-term investment strategies. In the UK in particular there have long been profit orientated pension funds and business executives increasingly remunerated by stock options who have sought short-term profitability in preference to long-term growth. Thus, some pressures towards financialization were in place from as early as the nineteen sixties. While we are not for a moment denying the self-serving motivations of key economic agents, it should be recognised that there is a new set of emergent institutional connections through which the activities of the cast of relevant actors are mediated. It seems these new, only semi-institutionalised relationships, lacking both self-correcting properties and regulation, have at times shown destabilising potential. In these circumstances it is a relatively complex matter to work out the causal sequences arising from such interactions. Indeed, analysing what happened will show that several distinct groups are implicated, and it is clearly wrong to lay the blame at any one door.

Thus the proposal of Sayles and Smith (2006) which suggests that the behaviour of some individuals within the executive cadre of major companies can be indicted as being to blame for the problems of major US companies and beyond this, to an extent, they are also to blame for our more general economic problems as well. Describing what they take to be the self-serving and destructive actions of the "rogue executive", Sayles and Smith come close to saying that it is a few executive bad apples in the corporate barrel that are the problem; and if courses in corporate ethics were made compulsory on MBA programmes - presumably still alongside their exposure to advanced accountancy - all might still be well. But although it is clearly necessary to see the complicit actions of business executives as an important factor in producing the self-reinforcing change we now see, it is more plausible to see executives as opportunistically adapting to their circumstances, than it is to see them as constituting the main source of problems by themselves. A similar point is made in this special issue by Sikka and Willmott in regard to Charles Perrow's (2010) argument that "the meltdown was not an accident". Likewise, it is not banking practices, such as the conjoining of retail and speculative banking per se, and the excessive risk-taking that senior bankers clearly sanction, that is the root cause of the crisis. Of course, one would have wished that traditional bankers had been more acutely aware of the dangers and pitfalls of participation in the emerging finance capital system than they actually were. But the truth is that they too have been opportunistically adaptive rather than truly innovative. Hence, traditional banks and bankers are also to some extent victims of recent developments. That they have not suffered the consequences of their lapses is due to government interventions to bail them out, and government laxity in not disciplining them subsequently. The appropriate conclusion to draw is that it is to new institutions and practices that we must look for the sources of current instability.

It is therefore interesting but not surprising that elite analysts, who have looked at the influence of banking sector executives through interlocking directorships (Mizruchi, 2010), have found that the 
influence of banking executives per se actually declined in the period leading up to the global financial crisis. Focusing largely on the United States, Mizruchi argues that a fundamental reorganization of the US economy occurred from the early 1980s, with the demise of 'traditional' banks which were embedded in a relatively diverse capitalist economy and elite networks, and their replacement by 'financial innovators' who emerged in numerous organizational guises. It was these innovators, whose distinction it was to think of new ideas about how to use surplus capital and whose actions have been most formative in the new financialized capitalism. Of course they thought of themselves as simply locating and securing a steady and reliable stream of profit for clients and for themselves. But what distinguishes them is that they developed the range of new institutions, now collectively identified as the shadow banking system, and in so doing encouraged the development of an increasingly financialized, almost post-market form of organizational capitalism. One of their key initial inventions the private equity $(\mathrm{PE})$ organisation and its associated private equity funds - was not so very different from what has been seen before in terms of their profit making strategies and impact on financialization. With the PE fund we have another - and rather more effective - way of taking over, stripping out and reconfiguring the assets of public companies. As such, PE funds are the lineal descendants of the predatory conglomerate and the merchant bank which did very similar things to PE funds in earlier decades, only less systematically (Morgan, 2009).

PE funds and activist investors, when economic conditions are right for them, actively look for public companies they can buy and take private for a limited time. When they first look the companies they might acquire, they consider them as bundles of assets from which profits can be extracted. This is, of course, a very different point of view from that of the traditional business executive who is seeking growth and is willing to invest to secure it. When actually acquired by PE funds, however, companies are rationalised (by which is meant a range of things from simple reorganisation to asset stripping or selling off parts or some combination of these). Usually, in the medium term, such firms are returned to public ownership, typically with a much higher debt to asset ratio than before. Such practices are fairly obviously aligned with and give support to the process of financialization, because what they do encourages firms and their assets to be considered mainly as sources of revenue having a potential which can be actively extracted. However, it is also important to note that the fact that there are agents like this, primarily interested in maximising the extraction of surplus from company assets, will have an effect on the behaviour of executives of target companies, or of any company that might become a target. Fairly obviously, it is a rational strategy for incumbent managers to take out the surpluses that may make them attractive as takeover targets in the first place. Thus the existence of activist investors by itself induces financialization as an outlook and process in the economy at large. This is one of several instances where the new arrangements under discussion here exert an influence vastly greater than their size alone would indicate.

The process of financial innovation has no natural limit and has not stopped. In more recent years attention has been drawn to the activities of another type of specialised finance house, hedge funds (HFs). These funds are much more innovative in what they do, and can be identified as the new spearhead of the continuing financialization. What hedge funds attempt is not so much to suspend the action of markets (for equities and for corporate control) for a period whilst they extract value, as do PE funds. Instead they actively intervene in markets and, amongst other things, seek to make profits both from rising and from falling market movements. In the first paper in this special issue, Jan Fichtner looks at hedge funds in a general way and how they can be considered in the lead in the current stage of the transition towards a more thoroughly financialized form of capitalism. He notes for example that almost all hedge funds are legally incorporated in the "secrecy jurisdictions" - tax havens by another name already mentioned. He also notes that, despite the diversity of their activities, hedge funds tend to 
promote the financialization of markets by their trading activities. These funds actually account for a surprisingly high proportion of stock and commodity trades and so tend to make these markets even more highly sensitive. Executives who are already vigilant about their share price seek out and adopt only practices that seem likely to yield continuous good performance as judged by the markets. To do otherwise might well make them vulnerable to external control. Also, as Fichtner argues, there is a tendency for hedge funds to act in similar ways to PE funds and in some circumstances to act in concert with them. Thus by actions that are similar to those of private equity funds, they also promote the financialization of business corporations.

With hedge funds there is the recurrent suspicion that their actions actually influence the prices of the securities in which they are dealing, bringing about price movements that are advantageous to them. This is, of course, to subvert what economists have usually taken to be the main purpose of markets, which is to fix the price independently of both buyers and sellers. This in itself would not be of much note, since there is so much manipulation of prices today, if these organisations were unimportant and marginal actors whose activities had very little impact. Unfortunately this is far from true. Both Jan Fichtner and Jamie Morgan, who also contributes a paper to this special issue on hedge funds, suggest that although hedge funds are tiny by comparison with the global stock of capital, they wield an influence greatly disproportionate to their size. Among other things, Fichtner reports for example that hedge funds account for $40 \%$ of the trades of major international stock markets, and more significantly yet, up to $80 \%$ of the trades in high yield derivatives. In a paper that takes us into areas that might seem specialized to some readers of this journal and require a grasp of some usually arcane intellectual procedures, Jamie Morgan analyses the activity of the type of hedge fund that represents the majority of funds in this increasingly concentrated sector. The depth of Morgan's analysis more than justifies any effort required to understand the material. Such funds operate in the major equity markets, where as Morgan also shows, they are responsible for a surprisingly high proportion of all trading. He shows how these funds make money from very small margins realised by the use of extremely high volumes of high value trades. Morgan candidly suggests that, such is the volume and range of their activity, that they can be seen at times to be enacting the whole market, and not just the markets for selected equities. If true, the implications are significant indeed.

Defenders of hedge funds argue that they bring a very high level of responsiveness to markets. However, there is a question as to whether this is always desirable. As we have suggested, they encourage a short term calculation of benefit and discourage long-term investment, which are policies that inherently disadvantage manufacturing industry. If it can be added to this that they influence the outcome of market processes to their own advantage, then it becomes questionable whether they contribute anything of value to economic relations. However, it is also suggested that hedge fund activities are risky for investors - and this is supposedly the key indicator of entrepreneurial activity. Surely hedge fund managers should not be denied the opportunity to take risks? This conveniently ignores the fact that hedge funds are designed, as Jamie Morgan's paper shows here, to take the risk out of market trading. In normal trading conditions advantageous trading without risk is what many of them do. The riskiness for them enters when markets become unstable and move against predicted trends, conditions which many think their own actions often help to bring about. It is true, for example, that the trading in the infamous collateralized debt obligations (CDOs) the defaulting on which precipitated the housing finance crisis which later became the general financial crisis, was hugely facilitated, and grew into a bubble, by the operation of hedge funds which, at one point, were responsible for $80 \%$ of the purchases of this class of security. In addition, as Fichtner and Morgan both argue, the resulting crisis was made considerably worse by the fact that some hedge fund managers anticipated the bursting of the bubble and shorted the CDO market by buying up the 'insurance' against default (the credit 
default swaps or CDSs) very cheaply. As a result they made huge profits for themselves, but in the process greatly deepened the difficulties for those continuing to hold CDOs. In short there is good reason to think that hedge funds were key actors in both precipitating the initial financial crisis and in intensifying its effects. The riskiness of what they did was as unnecessary as the results were unacceptable.

In common with the work of Fichtner and Morgan on hedge funds, all the papers in this special issue explore, in their different ways, the decisional behaviour of members of different factions within the capitalised elite, and consider how they contribute to more general processes. Our analysis here shows that by different routes their actions conform to a particular model of conduct comprising of the elevation of short-term financial return above all other considerations. In this particular form of financialized capitalism, financial measurement has become the primary if not the sole yardstick whereby success is calculated, both in terms of investment decision-making, and extending to measurement of the success of executives, whose worth is increasingly represented not in terms of a broader symbolic capital in the Bourdieuian sense, but directly and specifically in terms of extravagant awards of incomes and assets.

\section{Financial measurement, financialization and the transformation of the TNC}

Financial measurement represents not only a technique for exercising financial control, but in some ways even more importantly, it affects the nature of social relationships within the economy. Rather than viewing an important element of strategy towards its workforce as involving investment in the skills and loyalty of their 'human resources', as mainstream management ideas would have it, in financialized capitalism immediate revenue streams are paramount, with long term cultivation of assets subordinated to relatively short term value realisation. In such contexts, the work even of white collar employees is often routinized as far as possible and measured and assessed according to quantitative performance targets. Supervision has also become highly standardised, including the rationale that is typically offered concerning the effectiveness of the approach. Opportunities for participation within such managerial regimes are usually limited. Leo McCann's paper in this collection reports the findings from his study of the attitudes and outlook of employees working in banks and insurance companies in Britain. He explains how the work of the employees he interviewed had been subjected to routinization by the extensive use of information technology and business systems software, within precisely the kind of managerial regime described here. He finds that much of the work of lower level employees (and their supervision) is reduced to highly predictable routines that do not engage the employees' creativity or, for that matter, invoke their loyalty. The attention of strategic management is not focussed on these basic areas of the banking and insurance businesses, but this study and others show that the effects of such systems on employee morale and willingness to criticise their managers are noteworthy. Traditionally banking and insurance have not been noted for the willingness of their employees to dissent from - or even to criticise - the actions of their employers. However, it is surely likely that critical employee responses will become more common as organisations are increasingly subjected to financialization.

However, perhaps the most obvious effect of financialization is in the way that the organisation is restructured. Large hierarchical structures epitomized by Hymer's (1970) model of the transnational corporation are dismantled both in order to 'unlock' the unrealised value potential supposedly 
contained within such structures, but also to enable the ready valuation (and potentially the 'marketization') of the different parts of a company's assets. This in turn leads to the reorganization of businesses into a large number of relatively small and autonomous entities held under the strategic control of a central holding company. Whether this holding company is or is not owned or controlled by a publicly quoted firm or a private equity fund, does not matter very much: it will still be managed primarily through the reaching of financial targets. A financialized management strategy, in which all assets are assigned a value and each is allocated an expected return on capital employed, is now overwhelmingly standard business practice. In the circumstances it is surprising how few researchers in organisational studies have developed realistic accounts of the organisation structures that have emerged. Ackroyd $(2002,2007,2010)$ has produced a model from his research into British firms that he labels the 'capital extensive firm' (CEF). A similar approach is found in the work of Harland Prechel, which describes the new structure being widely adopted by American companies. Prechel identified what he called multi-subsidiary form or multi-layered subsidiary form or MSF (Prechel, 1997; Prechel and Boies, 1998; Prechel and Morris, 2010). These models - the CEF and the MSF - have much in common, such as the ubiquitous assessment of performance of the various assets of a company and the willingness of senior managers to see them as the source of separate revenue streams.

A key point is that the subsidiaries within a MSF/CEF are seen as units that can be traded from one firm to another, and also transformed by financial engineering, such as through the securitization of their revenue streams, as well as being further dismembered into smaller marketable chunks, or simply wound down or sold off if and when they are no longer profitable. This modular form of organization has the valuable quality of limiting the risk of a firm as a whole haemorrhaging from the losses arising from unexpected events - the collapse of demand in a particular market, a class action for damages or a contagious labour conflict. The last of these sometimes occurred in hierarchically organised Fordist corporations, where unions typically represented workers across the entire company and would monitor and resist efforts by the firm to introducing differential employment conditions and to 'divide and rule'. The MSF structure also of course facilitates and promotes off-shoring, engendering minimal resistance and conflict because workers in small autonomous firms are unlikely to be able to generate wider coalitions to oppose outsourcing effectively. The MSF model also tends to fractionate the managerial workforce between a strategic or financialized elite located mainly at the strategic centre, and operational and production managers mainly located in the autonomous firms. This permits a small corporate elite within the holding company to enrich itself while also being insulated from the divided loyalties of the operational managers who need to motivate workers in order to achieve production and financial targets and naturally come to share common viewpoints and interests in the future of their unit. However, we can also surmise that the MSF/CEF detracts from the concept of corporate loyalty that was the hallmark of the 'Organization Man' of the 1950s (Whyte, 1956; Sennett, 1998). Thus, just as the corporation is dismantled into smaller and smaller marketized units, so the individual employee too, faced with the employer's lack of long term commitment, also views the firm in purely instrumental terms, taking opportunities to jump into more advantageous positions and limiting the ability of the firm to act as a repository of embedded human capital.

The phenomenon of financialized capitalism that we are describing, therefore, represents a new phase of capitalist development with its own characteristics, dynamics, and points of weakness. In this special issue we are examining particularly the connections between the policies and practices of transnational corporations (TNCS), other large organizations (including financial institutions), and international economic crisis. As we have noted, while the causes of the current crisis are often ascribed to specific practices of specialized financial institutions and their creation of complex and unmanageable financial instruments this explanation focuses on only one overt manifestation of a by now widely extended 
mode of economic organization. Since well before the 2008 banking crisis, large corporations dispersed across the world have been undergoing fundamental transformations with the objective of increasing profitability through disarticulation of their structures as we have described. The introduction of much more flexible structures in the form of the MSF/ CEF brings with it the possibility of realising profits both through production itself including by outsourcing and off-shoring, but increasingly through the use of business processes as a platform for value extraction through a burgeoning variety of different vehicles including securitization of revenue streams, vesting of value in brands and other intangibles, the disembedding of financial and other consulting services and their charge against productive revenue streams, etc.

These developments, in which productive processes - whether resulting in the outputs of goods or services - are parcelled into subcomponents, not only have a significant impact on the economy, but also on the social structure. Although not immediately apparent, it is nonetheless evident on careful analysis that there are changed relationships underway between a reorganised capitalist class and subordinate classes nationally and globally. The shift of production from a developed economy (with its well-regulated and relatively secure working environments) to developing countries (where there are often unregulated sweatshops) graphically illustrates the point. In the developed countries a century of generally improving working conditions is under threat, whilst it is difficult to regard the new status of unskilled factory workers in developing countries as enviable, or often much of an improvement on their traditional situation. Thus, the institution of the value chain has a huge (if partially hidden) impact on the balance of forces between elites and the working population both in developed and developing countries. As Smith (2012) notes, outsourcing and financialization are intimately interlinked. Not only does a financialized approach to production provide a calculative logic to decisions about business process disarticulation and outsourcing, financialization in its broader understanding provides the potential for elites to extract the super-normal profits which have been made possible by off-shoring, and to realize them largely in tax havens and quasi-havens such as Luxemburg and the Irish Republic. At least since the investigations that followed the Enron and WorldCom collapses, it has been widely acknowledged that such practices as the manipulation of asset values by shifting them off the balancesheet, the avoidance of corporation taxes by realizing profits offshore, and the misrepresentation of revenues through creative accounting, are widespread amongst companies internationally (Syal, 2012).

\section{The behaviour of executives and the complicity of key professions}

We have argued that the changing organization of TNCs and other large corporations is part of a general process of capitalist reorganization which both is driven by, and gives further impetus to, the process of financialization. Among the phenomena noted is the multiplication of the transactional nodes within business processes (in global capitalism, transnational value chains) at which points a proportion of the value created through the chain may be realised. While some of the highly developed financial structures that have been invented are definitively fraudulent, such as the Madoff Ponzi scheme, the possibility of corporate malfeasance in ordinary companies has been greatly increased by the particular corporate and regulatory law reforms inspired by neoliberalism (Prechel and Morris, 2010). The business corporation today embodies the capacity to construct and govern value chains in which the value produced can be channelled in different directions - to be realised as profits in any number of possible locations. Indeed, in the US in recent decades there were specific repeals of the tax regulations making it easier to devolve tax liabilities to offshore locations. Given the values implicit in 
financialization, it should not surprise us that the realisation of profits often occurs in places where taxation will be minimal and well beyond the reach of state revenue authorities.

By 2012, in the context of the continuing crisis of state finances, and aided by pressure from activist groups such as Occupy Wall Street and UK Uncut, not to mention public interest research by organizations and networks such as Tax Justice', some politicians have begun to explore the nature and extent of the leaching of corporate revenues away from the states in which they are generated. Hearings held in the UK Parliament in November 2012 revealed a few of the plethora of different instruments and mechanisms that major transnational corporations routinely use in order to realise value in locations of their choosing. For example, the book and consumer goods internet giant Amazon pays taxes on European sales through its Luxemburg subsidiary, a country with a population of 500,000, or one-thousandth the population of the European Union as a whole, but with conveniently low corporate taxes as well as strong secrecy laws. The pharmaceutical giant Glaxo Smith Klein, similarly, used Luxembourg to avoid taxes through a scheme whereby its subsidiary headquartered in that country loaned over $f 6$ billion to its UK office, which then repaid the loan with interest of $£ 124$ million, that was taxed at only $0.5 \%$ in comparison with the $28 \%$ that would have been payable in the UK (BBC, 2012). Similarly, in 2011 Vodafone realised profits of $f 1.6$ billion in the small tax haven country of Switzerland, despite having minimal operations in that country; profits on which it paid less than $1 \%$ in corporate tax (Newman, 2012). These examples are not in fact unrepresentative of the practices of large firms in general, most paying close to zero (though they often quote employee income tax as their own contribution).

It is not at all surprising that the behaviour of corporate executives should support policies of financialization, and to be increasingly driven by calculations of short-term value realization. On the other hand, the extent of the involvement of key professionals in these processes, and the vigorous support they have lent to them, is not widely known. It is surprising to some, given the historical rhetoric of the professions concerning their embodiment of the public interest, how little independence the professions have actually shown from their corporate clients. Indeed there has been a quite extraordinary growth of the professions whose skills are required to facilitate corporate change, so that in one sense the power of the professionals has seldom been greater. In recent decades very large commercial law practices have emerged, typically based in London, for which the provision of legal services to MSF/CEF companies with their need for changed structures, loopholes and rationalizations, is the main line of work. Every new investment vehicle and every new contract contributes to the revenue stream of such firms. Ensuring that there are legal firewalls between business entities, and the legal work involved in buying and selling subsidiaries is considerable and earns large fees.

The commercial law 'factory', employing very large numbers of lawyers has become a key feature of the organisational landscape. Legal firms with hundreds of partners and thousands of employees now not only exist but are commonplace in Britain (Ackroyd and Muzio, 2007). However the scale of these companies and their operations pales into insignificance in comparison with the growth of accountancy. Accountancy is the business service most required by financialized capitalism. Today there are approaching 300,000 practicing accountants in Britain (up by nearly a third since 2001), and the profession continues to grow at a phenomenal rate. The UK already has the highest number of accountants per capita of any country in the world; and there are more accountants in Britain than in the whole of the rest of the EU taken together. If the numbers of accountants per head can be thought of as a measure of the extent of financialization, then Britain is well ahead of the game. 
The extremely thorough article by Prem Sikka and Hugh Willmott in this special issue looks at the place and role of the large accountancy firms in helping to facilitate tax avoidance by individuals and large firms. As we have seen it is a key feature of financialization to extract value and to regard assets as sources of value. It should be no very great surprise that major corporations seek to minimise the amount of this value that is taken away through the payment of taxes. There is ample evidence that they succeed. Sikka and Willmott suggest that only 210 of the 700 largest British companies paid any corporation tax at all, whilst most large companies, if they do pay corporation tax, do so at an effective rate well below that paid by the individual taxpayer. There is much evidence also that the largest companies are the most adept at avoiding tax. Certainly, the full extent of this avoidance is actually unknown, but there is ample evidence in this paper that the willingness of accountancy firms to devise new schemes on a continuous basis is clear. What is perhaps most startling about Sikka and Willmott's account is the extent to which the misbehaviour of firms and their collusion with the major accountancy is widely known but not effectively discouraged at the highest levels of the government and the professional regulatory bodies. Sikka and Willmott present many examples of what has been called elsewhere the 'revolving door' (Hacker and Pierson, 2010). In this arrangement, top personnel move between positions in the large accountancy firms, the regulatory agencies and the tax authorities. Sikka and Willmott suggest that one such example looks like the foxes being been put in charge of the hencoop. This sort of practice is one of many indications that there is actually a high level of agreement (or less charitably put, self-interested collusion) over policy amongst economic elites.

While the structures and management strategies of large corporations have undergone rapid and radical transformation (Clegg, 2011; Reed, 2011), the causes and consequences of these changes are seldom studied systematically. Many organization theorists and economists, for example, continue to think in terms of corporate change being related to simple exchanges between the organization and its environment, between the corporation and its markets. Academic comment has largely addressed narrow and technical issues. Where key issues have been explored, such as the need for corporate governance reform (McNulty et al., 2005) and the extent to which strategy formation is driven by financial considerations rather than product markets (Froud et al., 2006), these discussions insufficiently connected with one another or updated in the context of recent developments. While such

developments are beginning, there is a clear need for a much better understanding of the ways in which large corporations are actually implicated, and not simply complicit, in the processes of socio-economic change that have led to the current global economic crisis. There is a need to explore more deeply the nature of the linkages between finance capital, TNC strategies and the policies of governments, as it is becoming clear that there is a surprising degree of mutuality inherent in these relationships. Very little attention has been paid to the developments in the organization of international capitalism, conflict and class dynamics; however see Sklair (2002), Murphy (2012) and the concluding discussion in this paper.

\section{Effects on the global financial system}

It is important to remember that, as significant as the developments we have considered in this paper are, the emergent form of financialized capitalism we have been analysing in this special issue does not yet cover the whole world. It is true that the ideology of neoliberalism is pervasive not only in Britain and the USA, but shows every tendency to be spreading throughout Europe and much of the rest of the developed world. There are powerful agents of dissemination spreading these ideas and the associated patterns of organising. It is surprising to see just how receptive business people in European countries, 
who do not have the Anglo-Saxon cultural heritage of laisser-faire economics (and from which the more virulent form of financialized capitalism we are now seeing has developed), are to the new institutions and their associated values. Here the monopoly which American and British business services groups have must not be under-estimated. The framework of commercial law, which now forms the basis of almost all trading relationships throughout the world, is of course American, being an outgrowth of the British common-law principles. As Sikka and Willmott also document in the course of their contribution, the Anglo-Saxon business services groups - the accountants and consultants - who are aggressively selling ideas about forms of organising and managing businesses that are uncannily similar to the patterns that we have seen in Britain and the USA - are present in almost every country in the world.

It is of course also true that neoliberal doctrine offers powerful incentives to business leaders to conform with the patterns of action endemic to it. The value extraction process which is central to financialized capitalism rewards top business executives extremely well. This is because the agency problem which economists perceived, in which there was supposedly a difference between the interests of managers and owners, was solved by making business executives substantial shareholders themselves and by tying their remuneration tightly to short-term improvements in their share price. In continental Europe and Scandinavia, of course, there are some very different traditions of company governance that limit the tendency of managers to manage in their own interests and those of business owners. In countries like Germany, Sweden and Austria, many small businesses are already privately owned with only a small number of shareholders who are usually family or close kin. In these circumstances owners typically do not generally see their interests as different from those of the management. In many countries outside the UK and US too, where there is significant public ownership of shares, not all shares carry the same rights of ownership, so control and ownership are separated. Also, of course, with major companies there is the fact that trade unions are represented on company boards, so this is also a check on companies being sold or having excessive amounts of value extracted from them. Nevertheless, there are relentless pressures for 'reform' of these supposedly 'archaic' relationships, and some business people - particularly the members or aspiring members of the elite of international managers - will be susceptible to adopting neoliberal practices. Jan Fichtner suggests here that a higher proportion of German companies are becoming vulnerable to takeover by PE funds as the number of 'anchor investors' reduces. The shift in values towards neoliberalism in formerly corporatist economies is often palpable.

The fact that the world markets for large-scale finance capital are located in the main centres of financialized capitalism (New York and London) is also of the first importance in disseminating the attitudes and values of this system. Every borrower is subject to the terms and conditions under which loans are transacted. This is of course a truism, but it is as well to recall that these conditions are particular ones which carry with them a strong educative potential. These particular terms and conditions suggest to any observers that indebtedness must always be repaid whatever the consequences, and that obligations to lenders must always override all other types of obligation. We may contrast this with the repayment conditions that are contrived between German banks and their major industrial clients, in which the bank and client firm are interlocked. Time was, of course, when the providers of very large loans to countries were vulnerable to debt repudiation. Although this has happened in modern times - such as in the Argentinian example in which $\$ 9$ billion of debt was repudiated as recently as 2001 - but the fact is not given a great deal of prominence. In the Eurozone it is no longer an option for individual countries to devalue. Also, under the current lending regime the conditions attached to indebtedness cannot be readily eased, whilst there is increasing repayment discipline built in. Thus the debt which an incautious borrower has taken on, be it a major player such as a government or not, can soon become an impossible imposition. The current Southern European 
economic crisis provides a nice illustration of the processes at work. Although there are significant variations to the scenario in this context because of the monetary union within the EU, what we now see is a re-run of financial crises that have been enacted in South East Asia and in Latin America in recent decades.

The scenario works out like this: as recession deepens some lenders become nervous about the riskiness of their loans and a proportion become averse to committing more capital. Another minority, who wish to secure their capital, sells out its debt to more aggressive lenders who may also insure (hedge) against the further decline in the currency. Such signs lead debt rating agencies - all the significant ones being American - to downgrade the standing of current investments, leading to a hike in the price of further loans which will now inevitably be needed to service existing debt. Downgrading of course causes yet more unease amongst lenders, and in due course further raises the cost of additional borrowing. The role of opportunistic lenders who seek profit from the worsening situation is crucial and should not be overlooked. Some investors - often led by hedge funds not inappropriately called vulture funds in this context - opportunistically insure against further falls in the value of the currency in question, putting them in a position to short the currency. Thus they will profit if their debts (often bought cheaply) are redeemed at face value, but profit even more from their hedging activities if borrowers default. Such lenders have no interest in a solution being found to the debt crisis, and resist debt restructuring. Such actions are abusive, but there is no means of preventing them. The best that can be said is that because of weakly developed institutionalisation and the almost complete absence of regulation, the emergent system shows potentially disastrous combination of instability and inability to correct itself (Lapavitsas, 2012).

However, although the Anglo-Saxon pattern of organising finance capital works effectively in many situations, it has suffered a setback as a result of our current problems. In the valuable final paper we publish in this Special Issue - by Barbara Weiss and Jay van Wyk - we have a wide-ranging survey of developments within finance capital in the world at large following the financial crisis. Weiss and van Wyk argue that gridlock amongst Western lenders following the recent financial crisis has provided many opportunities for other lenders to take advantage of the situation and make loans to cashstrapped companies. Such developments are of course difficult to research in a systematic way. The information that researchers need is difficult to find when it is available at all. Despite this, the authors here do establish that there are other patterns for the development of finance capital than the Anglo Saxon one. In their scheme of analysis Weiss and van Wyk contrast the forms of 'market structure' that significantly differ from the situation in which there is little regulation - as in the Anglo American pattern - from those in which there is significant control of capital markets either by companies and/or states. The picture that emerges is that there have been substantial developments since the emergence of financialized capitalism in Britain and the USA. Nowadays, instead of automatically channelling their surplus funds through the City of London, countries have set up their own capital funds - sovereign wealth funds - which are within their direct control. Some states - of which China is the most important example - increasingly use their control of finance capital, whether it is channelled through their banks or their major companies, as an instrument of foreign policy. As Weiss and van Wyk argue, the extent of these developments has been given a firm push by the locking up and dysfunction of the Western system of finance capital. If governments are not moved by some of the effects of the system of financialized capital we have been considering here, we think they should take note of this. There are large sections of the world that have either been ignored or abused by Western capitalism, that are now being supplied with finance with different strings attached. 
We have suggested that the epicentres of growth of financialized capitalism are Britain and the USA. In these countries, as we have seen, there are special reasons that initiated the characteristic pattern of institutions and practices and then extended its development. In consequence, this type of capitalism has developed much further and more rapidly than elsewhere. The jury is still out as to how far the effects of financialization will reach, and whether as is argued here, much of the rest of the EU and NAFTA is at risk of being drawn into it. But we should be aware that, for better or worse, the system we find emerging not only has obvious systemic weaknesses, it is in competition with financial systems promoted by other and often even less politically democratic regimes than our own.

\section{Changes in class relations}

There is an important dimension to the changes we have been reviewing here, which is often not accessed in academic discussions, or only rather inadequately so. This concerns the social class changes that are also a basic feature of the economic transformation we have been examining. The rise of financialized capitalism is underpinned by and indicative of changes in the class composition of the societies in which this form of capitalism first appeared and which have increasingly become subjected to it. In Britain it is clear that there has been the rise of a segment of the ruling class that derives its wealth from finance as opposed to industrial or commercial capital, and the practices and the ideological priorities of this group have been increasingly influential. This group has not only introduced the new institutions and practices we have briefly examined in earlier sections of this introduction, but it has also influenced government policies through the dissemination of its political ideology as well. It is the interests of this group that are most clearly enshrined in neoliberal political ideology. Amongst other things, these highly distinctive ideas have prioritised the rewards for the owners of capital and enshrined the pre-eminence attributed to profit-making. Given the weakness of the industrial economy in these respects, neoliberalism facilitated the sweeping away of the remaining corporatist policies and institutions associated with industrial capitalism. The restructuring of the economy by the development of transnational value chains has permitted the outsourcing of large parts of production to low wage, poorly regulated, and frequently repressive sites within developing countries to the detriment of the working class at home.

Only by standing back from the consideration of the corporation and the disarticulated business processes in which it is engaged, can the overall character of the emerging socio-economic system of financialized capitalism be clearly seen. The simultaneous reduction in labour costs achieved by outsourcing and the increasing share of value realised from remote locations suggests a growing internationalisation in the outlook of the owning class. But the most obvious effect of the adoption of financialization, which reveals its class based character, is in the growing levels of inequality noted in Britain and the US where the phenomenon of financialized capitalism is at its most developed, and where too we see the unmistakable signs of overt class frictions and conflict. In terms of growing inequality, the US Congressional Budget Office has reported that the share of overall income earned by the top $1 \%$ more than doubled from $9.1 \%$ of the total in 1980 to $18.8 \%$ in 2006; a period coinciding with the rise of neoliberalism and the establishment of financialized capitalism (CBO, 2009). In fact, the slogan of the $1 \%$ greatly overstates the size of the dominant elite in the United States. Paul Krugman, the Nobel Prize winning economist, noted that, "[B]etween 1979 and 2005 the inflation-adjusted, aftertax income of Americans in the middle of the income distribution rose 21 percent. The equivalent number for the richest 0.1 percent rose 400 percent" (Krugman, 2011). He also points out that, at the same time, several rounds of large tax cuts benefitting the wealthy were enacted, effectively magnifying 
the effect of the growing income inequality in benefitting the rich. Thus, wealth distribution also skewed even more heavily towards the top echelon; by 2010 the top one percent of the population in the US owned $40 \%$ of all wealth, an increase from one third in a twenty-five year period (Wolff, 2010).

A similar pattern can be observed in the United Kingdom. The Gini coefficient of inequality, which compares the proportion of incomes captured by those at the top versus those at the bottom of the income distribution, increased from 26 to 40 in the decade to 2009 (Monbiot, 2011), bringing the country closer to US levels of inequality than those in Continental Europe (where financialized capitalism has developed more slowly and encountered greater social resistance). The income share of the top $1 \%$ doubled to $14.3 \%$ in the thirty five years to 2005 (OECD, 2011). At the same time, the share of lower income employees declined precipitously; the bottom half of employees earned only $10 \%$ of GDP in 2010, compared to $16 \%$ in 1977 (Sikka, 2012). In the same period, the share including bonuses of the top $10 \%$ of earners rose from $10 \%$ to $16 \%$. In other words, income share lost by the poorest half of the workforce had found its way into the pockets of the top $10 \%$. Most tellingly, this widening income gap between the top and bottom coincided with progressively less social mobility in the United Kingdom, with the OECD - hardly an organization noted for radical criticism - remarking that the country's tax and social benefit systems have become less effective in redistributing income. A manifestation of the leaching out of state tax revenues in financialized capitalism, described in the previous section, is found in the decline in UK tax revenues between $1981-2$ and $2011-12$ from $45.5 \%$ to $37.8 \%$ of GDP (Sikka, 2012), a time period once again coinciding with the rise to predominance of financialized capitalism driven by neoliberal ideology, and a consequent diminution of both the state's capacity and its ambition to combat rising inequality (R Murphy, 2011).

Financialization, therefore, represents not merely a reorganization of the processes of capitalist production, but a particular class strategy of international elites to take advantage of the new conditions of international political economy that were opened through the intellectual and policy triumph of neoliberal thinking in the 1970s and 1980s. Without necessarily subscribing to theories of an organic international capitalist class (Sklair, 2002; Robinson, 2004), it is clear that the transnational organization of capitalism that is inherent in the financialized model depends on the existence both of a stable governance regime that provides assurance that production chains and networks can be reorganized without hindrance across boundaries, and profits realised avoiding most taxation. This in turn relies upon capitalist elites and supportive governments in the most important countries (both in the developed and developing world) sharing a common understanding of mutual interests and of the most appropriate governance regimes to facilitate financialized capitalism.

\section{Conclusions}

The deeply rooted nature of financialization within broader social and political life is reflected in the peculiarly conflicted character of political leadership in the neoliberal era: the Republican candidate for the US presidency in 2012 (who despite being defeated, secured $48 \%$ of the popular vote) wrapped himself in the flag in the traditional display of nationalist cant considered apropos for the leader of the free world', while simultaneously championing his qualifications as a successful businessman. The contradiction is that Mitt Romney's business acumen was largely acquired through his co-founding and leadership for over a decade of Bain Capital, a private equity / investment company that focused on highly leveraged buy-outs, outsourcing of business processes to China and other low-wage economies, and the innovative use of tax havens such as the Cayman Islands (where Bain Capital holds over 100 
investment funds) to avoid paying tax in the United States and other jurisdictions where Bain Capital assets actually operate (Shaxson, 2011, Fifield and McGregor, 2012; Corn, 2012). Only in an era where neoliberalization has extended far beyond the domestic economy and become instantiated in the value systems of large swathes of the population as well as amongst the elite, could someone be considered electable in a major Western country who has so assiduously built enormous wealth through the dismemberment of productive organizations, the disposal of the national workforce in favour of low wage foreign workers operating under repressive regimes (Selden and Jieh-Min, 2011; Ngai and Chan, 2012), and the realisation of profits outside the purview of national tax authorities. Nor is this increasingly denationalized elite restricted to the United States; senior members of Britain's governments - of all political stripes - as well as its senior bureaucrats, have long been closely linked with financialized capital, including private equity vehicles, outsourcing consultancies, and the channelling of wealth through tax havens (Times, 2008; Channel 4, 2012; Syal and Williams, 2012).

The demonstrable growth in inequality naturally coincides with the re-emergence, albeit often in new and non-traditional forms, of class conflict. Whereas in earlier periods, trade unions formed the front line of the battle for an equitable distribution of income and wealth, the reorganization of production chains across national boundaries and beyond the capacity of nationally-bound unions to challenge resulted in a long period during which inequality grew with relatively little resistance. This was facilitated by another feature of financialization, as discussed earlier, which was the unbridled growth of credit, particularly as extended to precisely those segments of developed countries' populations that were hardest hit by the outsourcing of production to developing countries. The credit explosion provided at the same time an expanded income stream from securities facilitating the further financialization of the economy, and a false sense of well-being among lower income citizens due to their new ability to purchase homes despite insecure and often declining income. By the late 2000s, the entire Anglo-American financial sector had effectively become a Ponzi scheme that was inevitably headed for a crash. Once the implications of the crash on the lives of ordinary people became clear, and especially after the initial Keynesian response was replaced by a more 'robust' neoliberal stance, the emergence of resistance was inevitable. This resistance is perhaps best epitomized by the spontaneous development in 2011 of the "We are the 99\%" movement. The 99\% movement targeted a financial elite that appeared both to have caused the current financial crisis, and yet to have maintained an inordinate share of income and wealth, as well as a disproportionate and self-interested voice in state and transnational policy making processes geared to resolving the crisis caused by financialization. Even as the initial impetus of the $99 \%$ movement subsided, conflicts in the peripheral areas of Europe deepened and became more entrenched as popular resistance towards bond holders' and their government backers mounted.

It would be a mistake, despite the signs of a Polanyian 'dual movement' of capitalist reorganization and working class resistance, to view the various anti-finance capitalism movements as representing an immediate and real threat to the continuing domination of finance capitalism. To begin with, the movements are generally lacking a coherent alternative to the existing order, reflected for example in the inability of Greece's popular left-wing Syriza movement to articulate specifically what steps it would take, if it assumed power, to respond to the austerity measures being imposed by the European Union (Albo, 2013). Similarly, once the initial euphoria of the $99 \%$ movement subsided, the lack of a corollary social base to that which the trade unions had enjoyed in an earlier period meant that the energy of the movement could quickly dissipate and effectively be lost as activists dropped out of the movement in search of incomes. More fundamentally, the problem of confronting globalized capitalism remains: citizens are physically located in particular places, while capital is able to move freely across borders, effectively sidestepping nodes of resistance. In an international environment where the standard of 
living of Western workers remains far above that of those to whom work is being outsourced in developing countries, the immediate possibilities of transnational resistance appear limited in the extreme (J Murphy, 2011; Wad, 2007).

Instability in emerging economies, already seen in 2013 in Turkey and Brazil, and potentially particularly explosive if the phenomenon spreads to China, is a more likely threat to the continued expansion of transnational value chains. The effective tripling of the global workforce since 1980, through the integration of China, India, and other Asian country workforces into the international production system (Smith, 2012a) was necessary in order to drive down production costs and discipline the Western workforce. However the relatively small proportion of the benefits of this newly transnationalized production that accrue to developing country workers has created a highly volatile situation in China and elsewhere, in which the limited payoff from sweatshop employment confronts the offshore workforce with the reality that participation in the consumption economy will remain a chimera for most. The exponential rise in incidents of explosive resistance over recent years is likely to continue (Ngai and Huilin, 2010), with increasingly more serious ramifications for overall system stability, that cannot indefinitely be suffocated by a combination of repression and concession. The willingness of developing country governments to offer up their workers for financialized capitalism will thus be constrained by the need to satisfy increasingly impatient populations while also ensuring the elite continues to enjoy its own benefits for managing the global integration of national workforces. It can be speculated that the smooth continuation of the mutually beneficial developed country - developing country elite alliance is somewhat unlikely, raising the risk of disruptions to the free international flows of capital and goods that are necessary for the continuation of international financialized production. In particular, the eminently contestable nature of governance of the value chain (and hence the location and distribution of value extraction), especially within financialized capitalism where so much of the value is captured by intangibles, will surely become a major issue as developing country elites and governments seek to assert their interests (Starosta, 2010).

\section{BIBLIOGRAPHY}

Ackroyd, Stephen (2002), The Organisation of Business. Oxford: Oxford University Press.

Ackroyd Stephen (2007), "The large corporation and the emergence of flexible economic systems: some recent developments in the UK", in Bengt Furaker, Kristina Hakansson, and Jan Karlsson (eds.), Flexibility and Stability in Working Life, London, Palgrave, 83-102.

Ackroyd, Stephen (2010), "Post-bureaucratic manufacturing? the post-war organization of large British firms", Chapter 8 in Stewart Clegg, Martin Harris, \& Harro Hopfl (Eds.), Managing Modernity: Beyond Bureaucracy? Oxford, Oxford University Press, 176-201.

Ackroyd, Stephen and Daniel Muzio (2007), "The reconstructed professional firm: explaining change in English legal practices". Organisation Studies 28 (5) pp 1-19.

Albo, Greg (2013), "The crisis and economic alternatives", in Leo Panitch, Greg Albo and Vivek Chibber (eds.), The Question of Strategy: Socialist Register 2013, Pontypool, Merlin Press, 1 - 20. 
BBC (2012), "Major UK companies cut secret tax deals in Luxembourg",10 May, available at http://www.bbc.co.uk/news/business-17993945.

Brenner, Robert (2006), The Economics of Global Turbulence: The Advanced Capitalist Economies from Long Boom to Long Downturn, 1945-2005. New York: Verso.

Brummer, Alex (2009), The Crunch: How Greed and Incompetence Sparked the Credit Crisis. New York: Random House Business Books

Brittain-Catlin, William (2005), Offshore: The Dark Side of the Global Economy. New York: Farrar, Straus and Giroux.

CBO (Congressional Budget Office) (2009), Historical Effective Federal Tax Rates, 1979 to 2006, Washington, $\mathrm{CBO}$, available at http://www.cbo.gov/ftpdocs/100xx/doc10068/effective_tax_rates_2006.pdf.

Channel Four News (2012), "Public sector outsourcing: the political connections", 29 August, available at http://www.channel4.com/news/public-sector-outsourcing-the-political-connections.

Clegg, Stewart (2011), Under Reconstruction: Modern Bureaucracies. Chapter 9 in Stewart Clegg, Martin Harris and Harro Hopfl (eds) Managing Modernity: Beyond Bureaucracy? Oxford: Oxford University Press

Corn, David (2012), "Romney Invested Millions in Chinese Firm That Profited on US Outsourcing", Mother Jones, July 11, available at http://www.motherjones.com/politics/2012/07/bain-capital-mittromney-outsourcing-china-global-tech.

Duncan, Richard (2003), The Dollar Crisis: Economics in the Age of Paper Money. Singapore: John Wiley (Asia)

Duncan, Richard (2007), The Corruption of Capitalism. New York: John Wiley

Fifield Anna and Richard McGregor (2012), "Romney releases tax return details", Financial Times, September 21, available at http://www.ft.com/cms/s/0/8fc4288e-03f9-11e2-b91b00144feabdc0.html\#axzz2C74gNsDA.

Froud, Julie, Sukdev Johal, Karel Williams and Adam Lever (2006), Financialisation and Strategy. London: Routledge

Harvey, David (2005), A Brief History of Neoliberalism. Oxford: Oxford University Press.

Harvey, David (2010), The Enigma of Capital and the Crises of Capitalism. London: Profile Books

Hacker, Jacob and Paul Pierson (2010), Winner Take All Politics: How Washington Made the Rich Richer. New York: Simon and Schuster

Hymer, S (1970), "The Efficiency (Contradictions) of MNCs", American Economic Review, 60, 441-448. 
Krugman, Paul (2011), "We Are the 99.9\%", New York Times, November 24, available at http://www.nytimes.com/2011/11/25/opinion/we-are-the-99-9.html.

Lapavitsas, Costas (2012), Crisis in the Eurozone. London: Verso.

McNulty, Terry, John Roberts and Peter Stiles (2005), "Undertaking Governance Reform and Research" British Journal of Management 16 (Special Issue) pp 99-107

Mizruchi, Mark S. (2010), "The American Corporate Elite and the Historical Roots of the Financial Crisis of 2008," in Michael Lounsbury and Paul Hirsch (ed.), Markets on Trial: The Economic Sociology of the U.S. Financial Crisis, Bradford, Emerald,103 -139.

Monbiot, George (2011), "The 1\% are the very best destroyers of wealth the world has ever seen", Guardian, November 7, available at http://www.guardian.co.uk/commentisfree/2011/nov/07/oneper-cent-wealth-destroyers/.

Morgan, Jamie (2009), Private Equity Finance: Rise and Repercussions. London: Palgrave MacMillan

Murphy, Jonathan (2011), "Indian call centre workers: vanguard of a global middle class?", Work, Employment \& Society, 25, 417- 433.

Murphy, Jonathan (2012), "Rise of the 1\%: An organizational explanation", paper presented at EGOS Conference, Helsinki, July 5.

Murphy, Richard (2011), The Courageous State: Rethinking Economics, Society and the Role of Government, London, Searching Finance.

Newman, Melanie (2012), "Vodafone: Undercover investigation exposes Swiss branches", Bureau for Investigative Journalism, March 6th, available at http://www.thebureauinvestigates.com/2012/03/06/vodafone-undercover-investigation-exposesswiss-branches/.

OECD (2011), Divided We Stand : Why Inequality Keeps Rising, Paris, OECD Publishing.

Ngai, Pun and Lu Huilin (2010), "Unfinished Proletarianization: Self, Anger, and Class Action among the Second Generation of Peasant-Workers in Present-Day China", Modern China, 36, 493-519.

Ngai, Pun and Jenny Chan (2012), "Global Capital, the State, and Chinese Workers: The Foxconn Experience", Modern China, 38, 383-410.

Perrow, Charles (2010), "The Meltdown was not an Accident" in Michael Lounsbury and Paul Hirsch (ed.), Markets on Trial: The Economic Sociology of the U.S. Financial Crisis, Bradford, Emerald, 307- 329.

Peston, Robert (2008), Who Runs Britain, and who is to Blame for the Mess We Are In? London: Hodder and Stoughton 
Plehwe, Dieter (2009), "The Origins of the Neoliberal Economic Development Discourse" in Mirowski, Philip and Dieter Plehwe, eds, The Road from Mont Pèlerin: The Making of the Neoliberal Thought Collective, Cambridge, Harvard University Press, 238 - 279.

Prechel, Harland (1997), "Corporate form and the state: Business policy and change from the multidivisional to the multilayered subsidiary form." Sociological Inquiry 67 (1) pp 151-174.

Prechel, Harland and John Boies (2010), "Capital dependence, financial risk, and change from the multidivisional to the multilayered subsidiary form". Sociological Forum, Vol. 13, No. 2 pp. 321-362

Prechel, Harland and Theresa Morris (2010), "The Effects of Organizational and Political Embeddedness on Financial Malfeasance in the Largest U.S. Corporations: Dependence, Incentives, and Opportunities", American Sociological Review, 75, 331-354.

Reed, Michael (2011), The Post-Bureaucratic Organisation and the Control Revolution. Chapter 10 of Stewart Clegg, Martin Harris and Harro Hopfl (eds) Managing Modernity: Beyond Bureaucracy? Oxford: Oxford University Press

Robinson, W. (2004), A Theory of Global Capitalism, Baltimore, Johns Hopkins University Press.

Roubini, Nouriel (2008), "The Rising Risk of a Systemic Financial Meltdown: The Twelve Steps to Financial Disaster", RGE Monitor, February 8, available at http://www.quartetfest.ca/documents/30239/12 steps NR.pdf.

Sayles, Leonard and Smith, Cynthia (2006), The Rise of the Rogue Executive: How Good Compnaies Go Bad and How to Stop the Destruction. New York: Pearson Education / Prentice Hall

Selden, Mark and Wu Jieh-min (2011), "The Chinese State, Incomplete Proletarianization and Structures of Inequality in Two Epochs", The Asia-Pacific Journal, 9, Issue 5 No 1, available at www.japanfocus.org/-Jieh min-Wu/3480.

Sennett, Richard (1998), The Corrosion of Character: The Personal Consequences of Work in the New Capitalism. New York: W Norton

Shaxson, Nicholas (2011), Treasure Islands: Tax Havens and the Men Who Stole the World. London: The Bodley Head

Sikka, Prem (2012), "Squeezing ordinary people's finances always leads to disaster", Guardian, April 23, available at http://www.guardian.co.uk/commentisfree/2012/apr/23/squeezing-ordinary-peoplefinances/

Sklair, Leslie (2002), The Transnational Capitalist Class, Oxford, Blackwell.

Smith, John (2012), Outsourcing, financialization and the crisis, International Journal of Management Concepts and Philosophy, 6, 19-44.

Smith, John (2012a), "The GDP Illusion: Value Added versus Value Capture", Monthly Review: 64 (3), 86 $-102$. 
Starosta, Guido (2010), "Global Commodity Chains and the Marxian Law of Value", Antipode, 42, 433 465.

Stiglitz, Joseph (2009), Freefall: Free Markets and the Sinking of the Global Economy. London: Allen Lane.

Strange, Susan (1998), Mad Money: When Markets Outgrow Governments. Manchester: Manchester University Press

Syal, Rajeev and Martin Williams (2012), Tory treasurer wants UK to become more like a tax haven, Guardian, 21 September, available at http://www.guardian.co.uk/business/2012/sep/20/torytreasurer-make-uk-tax-haven.

Syal, Rajeev (2012), "Amazon, Google and Starbucks accused of diverting UK profits, The Guardian, 12 November, available at http://www.guardian.co.uk/business/2012/nov/12/amazon-googlestarbucks-diverting-uk-profits.

Times of London (2008), "The Tories and the oligarch: key characters", October 21, available at http://www.thetimes.co.uk/tto/news/politics/article2026299.ece.

Wad, Peter (2007) “'Due Diligence' at APM-Maersk: From Malaysian Industrial Dispute to Danish Cross-Border Campaign", in: Bronfenbrenner, K. (ed) Global Unions.

Challenging Global Capital Through Cross-Border Campaigns, Ithaca NY, Cornell University Press, 40-56.

Whyte, William H. (1956), The Organization Man, New York, Simon \& Schuster

Wolff, Edward N. (2010), "Recent Trends in Household Wealth in the United States: Rising Debt and the Middle-Class Squeeze-an Update to 2007", Levy Economics Institute of Bard College Working Paper No. 589, available at http://www.levyinstitute.org/pubs/wp 589.pdf.

\footnotetext{
'http://www.taxjustice.net.
} 